\title{
Efek Prisma pada Pemakai Kacamata Single Vision
}

\author{
Hanna Nurul Husna, Ai Meri Yulianti, Itmam Milataka
}

Program Studi Optometri STIKes Bakti Tunas Husada, Tasikmalaya, Indonesia

\begin{tabular}{|c|c|}
\hline Info Artikel & ABSTRAK \\
\hline Histori Artikel: & \multirow{6}{*}{$\begin{array}{l}\text { Desentrasi lensa pada kacamata dapat menyebabkan efek prisma, dan dapat } \\
\text { menyebabkan berbagai keluhan penglihatan. Penelitian ini bertujuan untuk } \\
\text { mengidentifikasi profil efek prisma pada pemakai kacamata. Sebanyak } 89 \\
\text { mahasiswa STIKes Bakti Tunas Husada penderita miopia dan menggunakan } \\
\text { kacamata single vision berpartisipasi pada penelitian ini. Efek prisma } \\
\text { ditentukan secara resultan (binokuler) dengan menggunakan persamann } \\
\text { Prentice Rule. Hasil dari penelitian ini ditemukan bahwa efek prisma } \\
\text { horizontal pada pemakai kacamata dengan besaran terbesar }(0,0-2.0) \Delta \\
\text { sebanyak } 44 \text { orang dan didominasi pada arah base in. Serta efek prisma } \\
\text { vertikal dengan besaran terbesar } 6 \Delta \text { dominasi base up. Efek prisma ini dapat } \\
\text { menjadi salah satu faktor timbulnya keluhan penglihatan pada pengguna } \\
\text { kacamata. }\end{array}$} \\
\hline Diterima: 5 Juni, 2020 & \\
\hline Direvisi: 20 Agustus, 2020 & \\
\hline Diterbitkan: 1 September, 2020 & \\
\hline & \\
\hline $\begin{array}{l}\text { efek prisma } \\
\text { kacamata single vision }\end{array}$ & \\
\hline Keywords: & \multirow{4}{*}{$\begin{array}{l}\text { Lens decentration in spectacle wearer could induce prismatic effect and lead to } \\
\text { various visual problems. The aim of this study was to identify the profile of the } \\
\text { prismatic effect from } 89 \text { eyeglasses wearer (single vision) at STIKes Bakti } \\
\text { Tunas Husada. The prismatic effect was determined by resultant (binocular) } \\
\text { using Prentice's Rule. The finding reveals that there was horizontal prismatic } \\
\text { effect which has } 44 \text { eyeglasses wearer with a maximum value at }(0.0-2.0) \Delta \\
\text { base in dominated. Vertical prismatic effect was found with maximum value } 6 \\
\Delta \text { base up dominated. The prismatic effect could be one factor that induced } \\
\text { visual problem for spectacle wearer. }\end{array}$} \\
\hline prismatic effect & \\
\hline single vision eye glasses & \\
\hline Penulis Korespondensi: & \\
\hline
\end{tabular}

\section{PENDAHULUAN}

WHO (The International Agency foir the Prevention of Blidness, 2019) menyatakan bahwa terdapat 124 juta orang yang mengalami kelainan refraksi. Kelainan refraksi dapat terjadi karena berkas bayangan benda tidak jatuh tepat di retina (Sidarta, 2004). Berkas bayangan benda tersebut dapat jatuh di depan retina, yang disebut dengan miopia, dan juga bisa jatuh di belakang retina, yang disebut dengan hipermetropia. Penglihatan orang dengan kelainan refraksi dapat dibantu dengan menggunakan kacamata. Kacamata merupakan alat optik yang bekerja berdasarkan prinsip pembiasan (refraksi) cahaya (Giancoli, 2005).

Pada pemakai kacamata, sebelum cahaya masuk ke mata, cahaya melewati lensa kacamata. Untuk penglihatan yang nyaman, sinar harus melalui titik pusat optik lensa/optical center (OC) dan selanjutnya masuk ke mata. Jika sinar melalui OC lensa, maka sinar akan menjalar lurus dan tidak dibiaskan (Muhammed, 2016). Sedangkan jika sinar melewati bagian lain dari lensa maka sinar akan dibiaskan (Wakefield \& Bennett, 2000). Oleh karena itu, penempatan dan penyetelan lensa kacamata sangat menentukan bagaimana proyeksi sinar menuju mata. 
Berdasarkan penelitian yang telah dilakukan oleh Husna dkk (2018) diketahui bahwa beberapa optik jarang melaksanakan pengukuran kembali kesesuaian dan kesejajaran OC dan jarak antar pupil/pupil distance (PD) khusunya untuk lensa single vision. Padahal hal tersebut dapat menyebabkan desentrasi lensa yang berdampak pada berbagai keluhan penglihatan.

Saat sinar masuk ke pupil mata tidak melewati OC lensa, maka sinar tersebut akan mengalami penyimpangan. Besarnya penyimpangan tergantung dari kekuatan lensa, jarak sinar masuk ke OC, sudut sinar datang ke permukaan lensa, indeks bias bahan, sudut sinar keluar dari permukaan lensa (Bruce, 2013; Chapman, 2012). Sinar-sinar menyimpang yang masuk ke mata menyebabkan desentrasi lensa. Desentrasi lensa adalah ketidaksesuaian titik pusat optik/optical center (OC) atau titik pusat referensi utama dari posisi tengah frame lensa (Brooks \& Borish, 2007). Penelitian mengenai desentrasi lensa telah dilakukan oleh Husna \& Yulianti (2019), dan ditemukan bahwa pada mahasiswa pemakai kacamata single vision terdapat desentrasi lensa dengan jarak maksimum desentrasi (3-5) mm pada kedua mata.

Pembahasan lensa pasti akan berkaitan dengan prisma. Lensa dapat diasumsikan sebagai dua prisma yang disatukan. Oleh karena itu, peristiwa saat sinar menyimpang masuk ke mata dapat diilustrasikan seperti sinar melewati prima. Penyimpangan sinar yang masuk ke mata (desentrasi lensa) akan menciptakan efek prisma. Penelitian mengenai efek prisma dilakukan oleh Butler, Jowell, \& Clarke-Fall (2016) yang mengungkapkan tentang dampak penyimpangan OC lensa dengan PD pemakai, yaitu efek prisma, dimana terdapat $10 \%$ wanita dan $36.67 \%$ pria yang mengalami efek prisma secara vertikal pada kacamatanya. Efek prisma dapat menimbulkan keluhan penglihatan seperti astenopia, pusing, penglihatan ganda, dan penglihatan buram (Wilson, 2019).

Berdasarkan latar belakang di atas, penelitian ini bertujuan untuk mengidentifikasi efek prisma yang terjadi pada pemakai kacamata single vision di STIKes Bakti Tunas Husada Tasikmalaya. Dengan dilakukannya penelitian ini diharapkan menjadi dapat memberikan informasi kepada pemakai kacamata mengenai salah satu penyebab keluhan. Penelitian ini pun dapat dijadikan sebagai dasar penyuluhan bagi pemakai kacamata mengenai pentingnya fitting kacamata yang baik dan benar. Bagi civitas akademika sendiri, penelitian ini bermanfaat untuk menambah keilmuan di bidang Fisika khususnya yang berkaitan dengan Fisika Optik dan Fisika Kesehatan.

\section{METODE}

Sebanyak 89 mahasisya yang terdiri dari 9 laki-laki dan 80 perempuan, dalam rentang usia 18 sampai 22 tahun menjadi subjek dalam penelitian ini. Subjek penelitian dipilih berdasarkan kriteria inklusi bahwa mereka merupakan penderita miopia dan menggunakan kacamata single vision dalam aktivitas sehari-hari. Sebelum dilakukan pengukuran, subjek penelitian diberikan inform consent terlebih dahulu.

Langkah pertama pada penelitian ini, mata subjek disinari dengan menggunakan pen light sehingga menghasilkan pantulan pada matanya. Dari pantulan ini diukur jarak antar pupil (PD). Metode ini dinamakan corneal reflex method (Wilson, 2019). Selanjutnya, pada lensa kacamata subjek dicari titik pusat optik-nya (OC) dengan menggunakan lensometer manual (badal) dan ditandai.

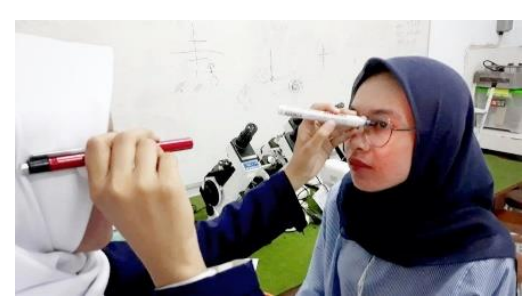

(a)

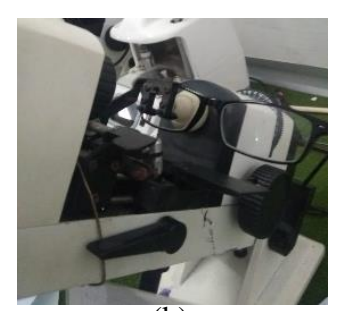

(b)

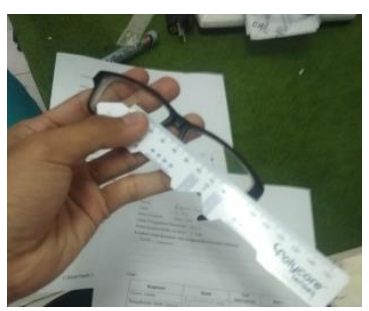

(c)

Gambar 1. (a) Pengukuran PD; (b) Penemtuan OC dengan lensometer; (c) Pengukuran jarak OC masing-masing lensa 
OC (optical center) yang dimaksud adalah titik pusat optik, dimana sinar yang bergerak di sepanjang sumbu optik (OC) ini akan melewati lensa tanpa pembiasan/penyimpangan. PD (pupil distance) yang dimaksud adalah jarak antara lokasi pupil kedua mata/Major Reference Point (MRP). Setelah data PD dan OC telah diperoleh, selanjutnya dilakukan pengukuran kesesuaian dan kesejajaran titik OC pada lensa dan PD. Jika OC dan PD sesuai dan sejajar maka data dikategorikan tidak mengalami desentrasi lensa, sedangkan jika OC dan PD tidak sesuai dan sejajar maka data dikategorikan mengalami desentrasi. Data-data yang mengalami desentrasi inilah yang selanjutnya diolah kembali untuk menentukan besar dan arah efek prisma dari lensa. Efek prisma dari lensa kacamata diperoleh melalui perhitungan dengan menggunakan persamaan Prentice Rule (Brooks, 1992).

$$
\Delta=c . f
$$

Keterangan:

$\Delta$ : efek prisma

$c:$ desentrasi/pergeseran dari OC lensa $(\mathrm{cm})$

$f:$ kekuatan lensa (Dioptri)

\section{HASIL DAN DISKUSI}

Prisma merupakan material transparan tipis dengan bentuk segitiga yang terdiri dari apex (sudut pembias) dan base (Smith dkk, 2002). Prisma dikategorikan menjadi prisma refraksi dan prisma ophthalmic. Prisma refraksi biasanya digunakan di bidang optik untuk menguraikan berkas cahaya, sedangkan prisma ophthalmic digunakan untuk koreksi kelainan penglihatan binokuler seperti heterophia dan strabismus (Chapman, 2012). Suatu prisma dikategorikan sebagai prisma ophthalmic jika memiliki sudut pembias (apex) kurang dari $10^{\circ}$. Dalam pembahasan ini, prisma yang dimaksud adalah prima ophthalmic.

Pembahasan prisma dan lensa tidak bisa dipisahkan satu sama lain. Lensa dapat diasumsikan sebagai dua prisma yang disatukan. Lensa cembung merupakan dua prisma dengan base yang menyatu, sedangkan lensa cekung merupakan dua prisma dengan ujung apex yang menyatu satu sama lain (Wilson, 2019).

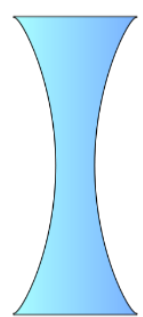

(a)

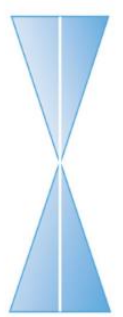

(b)

Gambar 2. (a) Lensa cekung; (b) Prisma dengan ujung yang menyatu membentuk lensa cekung (Keirl, 2014)

Lensa kacamata yang baik memiliki titik OC lensa yang sesuai dan sejajar dengan PD kacamata. Pergeseran antara kedua titik ini disebut dengan desentrasi lensa. Sinar akan melewati lensa tanpa pembiasan/penyimpangan jika bergerak di sepanjang sumbu optik (OC) (Muhammed, 2016). Sinarsinar lain yang memasuki lensa selain dari titik tersebut akan menyimpang (Wakefield \& Bennett, 2000). Besarnya penyimpangan tergantung dari kekuatan lensa, jarak sinar masuk ke OC, sudut sinar datang ke permukaan lensa, indeks bias bahan, sudut sinar keluar dari permukaan lensa (Bruce, 2013; Chapman, 2012). Sinar-sinar yang menyimpang dan masuk ke mata akan menciptakan efek prisma.

Efek prisma terjadi ketika sumbu visual pasien tidak melewati OC lensa (Milodot, 2009). Satuan dari efek prisma adalah prisma dioptri $(\Delta)$. Satu prisma dioptri didefinisikan sebagai deviasi sinar sebesar $1 \mathrm{~cm}$ dari sumber sinar terpancarkan sejauh $100 \mathrm{~cm}$ (Erickson, 2016; Smith dkk., 2002). 


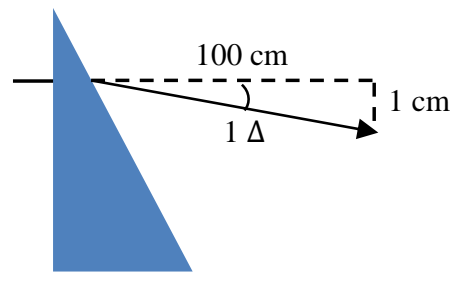

Gambar 3. Definisi satu prisma dioptric

Efek prisma merupakan satuan vektor, yaitu memiliki besaran dan arah. Besaran efek prisma dapat ditentukan dengan menggunakan Lensmeter ataupun berdasarkan perhitungan menggunakan Prentice's Rule. Salah satu kelemahan menentukan efek prisma dengan menggunakan Lensmeter adalah nilai efek prisma hanya dapat ditentukan dalam nilai satuan tanpa desimal. Untuk hasil yang lebih akurat, maka dalam penelitian ini digunakan persamaan Prentice's Rule. Berdasarkan persamaan (1), besarnya efek prima berbanding lurus dengan kekuatan lensa dan pergeseran titik PD dari OC. Oleh karena itu, ketepatan penempatan OC semakin penting dengan bertambahnya kekuatan lensa (Bruce, 2013).

Efek prisma dapat terjadi secara horisontal ataupun vertikal. Penelitian ini hanya membahas efek prisma yang terjadi secara horizontal. Perhitungan desentrasi dilakukan terlebih dahulu untuk mata kanan dan kiri. Setelah data desentrasi mata diperoleh, selanjutnya dilakukan perhitungan efek prisma untuk masing-masing mata. Karena manusia memiliki dua mata, maka perhitungan efek prisma dilakukan dengan menggunakan resultan, atau istilah kesehatannya secara binokuler (dua mata). Resultan dihitung dengan memperhatikan besaran dan arah efek prisma untuk mata kanan dan kiri. Jika base mata kanan dan kiri searah maka resultan efek prisma dijumlahkan, sedangan jika base mata kanan dan kiri berlawanan maka resultan efek prisma diselisihkan (Poudel, 2019).

Sebanyak 89 mahasiswa yang terlibat dalam penelitian ini. Akan tetapi karena beberapa mahasiswa ada yang bukan miopia murni (campur dengan astigmatism) maka data diseleksi dan diperoleh 76 data untuk diolah. Data mahasiswa yang mengalami miopia-astigmatism tidak disertakan. Berdasarkan hasil pengukuran terhadap 76 mahasiswa, diperoleh data mengenai distribusi besaran efek prisma horizontal binokuler yang disajikan pada Tabel 1 di bawah ini.

Tabel 1. Distribusi Efek Prisma Horizontal Binokuler

\begin{tabular}{ccc}
\hline Besaran Efek Prisma $(\Delta)$ & Frekuensi & Persentase (\%) \\
\hline $0,0-2,0$ & 44 & 57,8 \\
\hline $2,1-4,0$ & 7 & 9,2 \\
\hline $4,1-6,0$ & 7 & 9,2 \\
\hline $6,1-8,0$ & 6 & 7,8 \\
\hline $8,1-10,0$ & 4 & 5,3 \\
\hline $10,1-12,0$ & 1 & 1,3 \\
\hline $12,1-14,0$ & 2 & 2,6 \\
\hline $14,1-16,0$ & 1 & 1,3 \\
\hline $16,1-18,0$ & 1 & 1,3 \\
\hline $18,0-$ ke atas & 3 & 3,9 \\
\hline
\end{tabular}

Pada tabel 1 di atas menunjukkan bahwa sebaran efek prisma terjadi pada rentang $(0,0-18) \Delta$ ke atas. Efek prisma yang paling banyak terjadi pada pemakai kacamata terdapat pada rentang besaran $(0,0-$ $2,0) \Delta$ sebanyak 44 orang $(57,8 \%)$. Pada penelitian ini, efek prisma juga terjadi secara vertikal. 
Terdapat empat pasien yang mengalami efek prisma vertikal dengan besaran efek prisma $1,2 \Delta ; 1,825$ $\Delta ; 0,975 \Delta, 6 \Delta$.

Efek prisma tidak hanya dapat ditentukan besarnya tetapi juga arahnya. Arah pada efek prisma dapat ditentukan berdasarkan base prisma-nya (Wilson, 2019). Pergeseran OC secara horisontal akan menghasilkan arah base in dan base out, sedangkan pergeseran OC secara vertikal menghasilkan arah base up dan base down (Bruce, 2013). Untuk lensa cekung dikatakan base out jika jarak antara kedua titik pusat optik (OC) lebih kecil dari pada jarak antar pupil (PD). Dikatakan base in jika jarak antara kedua OC lebih besar dari pada PD (Gambar 4).

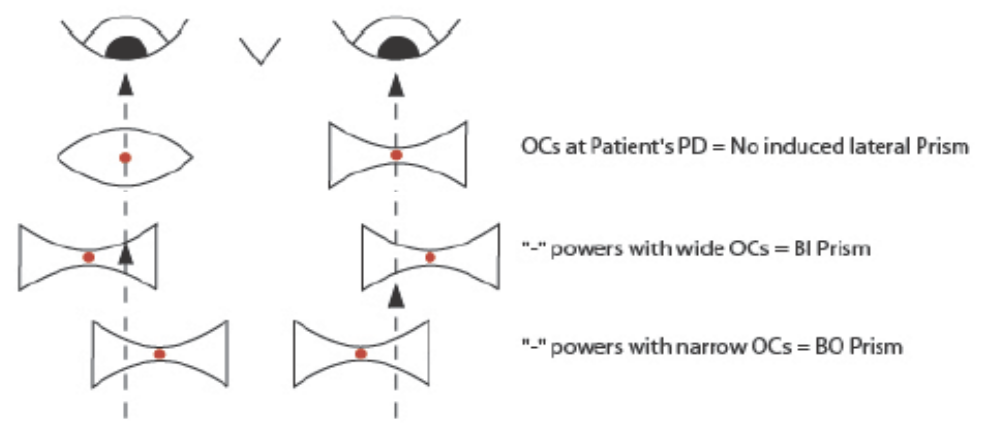

Gambar 4. Penempatan OC dan PD serta Hubungannya dengan Arah Efek Prisma (Keirl, 2014)

Tabel 2 di bawah ini menyajikan distribusi frekuensi arah efek prisma secara horisontal secara binokuler.

Tabel 2. Distribusi Arah Efek Prisma

\begin{tabular}{cc}
\hline Arah & Frekuensi \\
\hline 0 & 19 \\
\hline Base Out & 23 \\
\hline Base In & 34 \\
\hline Base Up & 3 \\
\hline Base Down & 1 \\
\hline
\end{tabular}

Berdasarkan tabel 2 di atas diperoleh hasil bahwa semua responden diketahui kacamatanya ada yang tidak mengalami efek prisma, dan ada juga yang mengalami efek prisma dengan arah base in, base out, base up, dan base down. Dari table di atas pun diketahui bahwa resultan arah efek prisma horisontal yang paling sering terjadi adalah base in sebanyak 34 orang.

Dari data-data yang disajikan di atas dapat diketahui bahwa banyak mahasiswa pemakai kacamata yang mengalami efek prisma. Meskipun besaran dari efek prisma tidak terlalu besar dan kekuatan lensa-nya pun tidak besar, tapi setidaknya hal ini akan menyebabkan ketidaknyamanan pada penglihatan. Perbedaan besar dan arah efek prisma dari masing-masing mata akan menyebabkan ketidakseimbangan penglihatan baik secara horisontal dan vertikal.

Saat sinar masuk melalui prisma, maka sinar tersebut akan dibiaskan menuju base prisma (Smith et al., 2002). Begitu pun dengan lensa yang mengalami efek prisma. Ketika mata melihat objek melalui prisma, maka bayangan benda akan muncul semakin dekat ke apex. Efek prisma menghasilkan efek "menarik mata" menuju apex dari prisma (Chapman, 2012) dan akan terjadi pergeseran bayangan yang terbentuk (Bruce, 2013). Pergeseran pembentukan bayangan inilah yang menjadi penyebab ketidaknyaman penglihatan terutama pada pemakaian pertama kacamata. 


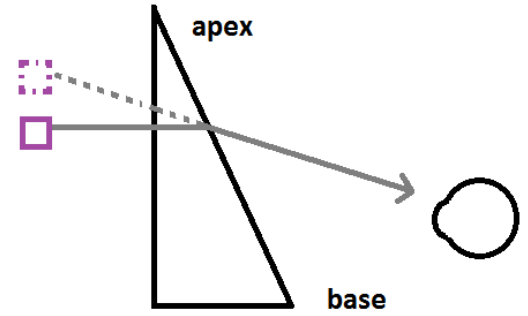

(a)

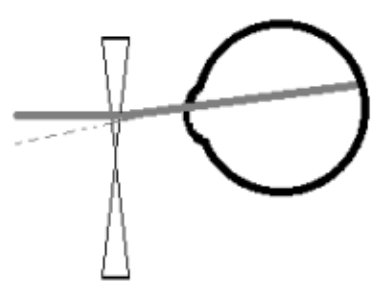

(b)

Gambar 5. (a) Sinar masuk melalui prisma akan dibiaskan menuju base; (b) Pembentukan bayangan menuju apex saat mata melihat melalui prisma Sumber: (Erickson, 2016)

Ketidakseimbangan koreksi penglihatan di kedua mata disebut dengan anisometropia (McCarthy, 2010). Anisometropia akan berpengaruh secara signifikan jika terjadi ketidakseimbangan secara vertikal. Setiap ketidakseimbangan penglihatan yang terjadi, mata secara otomatis akan melakukan kompensasi dan adaptasi. Bruce (2013) mengungkapkan bahwa untuk ketidakseimbangan penglihatan dapat direduksi dengan menaikkan dagu sampai dicapai nilai minimal ketidakseimbangan (kurang dari $0.5 \Delta$ ). Dalam mengatasi efek prisma dan ketidaknyaman penglihatan, pada lensa single vision, pemakai kacamata dapat memposisikan dagunya naik atau turun agar penglihatan sejajar dengan sumbu penglihatan (optical axis). Jika kompensasi dan adaptasi ini dilakukan secara terus menerus tanpa perbaikan, maka akan terjadi muncul keluhan penglihatan seperti sakit kepala dan mata lelah (Moodley et al., 2011; Valiyaveettil, Prabhu, T., \& Vallon, 2018).

Sebagian dari responden mengeluhkan ketidak-nyamanan penglihatan pada saat pemakaian kacamata pertama-nya. Mereka mengeluhkan bahwa penglihatannya terasa pusing, terlihat ganda dan kabur. Keluhan penglihatan ini diduga merupakan salah satu keluhan yang diakibatkan salah satunya karena efek prisma. Tapi keluhan penglihatan ini hanya berlangsung pada pemakaian pertama saja tapi tidak dipemakaian selanjutnya. Mata melakukan adaptasi terhadap ketidaknyamanan pemakaian kacamata sehingga pada akhirnya mata nyaman dengan penglihatan barunya. Meskipun demikian akan ada dampak yang ditimbulkan dari "pemaksaan" kacamata tersebut dalam jangka waktu pemakaian yang lama. Dampak tersebut muncul karena mata dan otak bekerja lebih keras dalam menterjemahkan persepsi penglihatan sehingga menimbulkan keluhan seperti sakit kepala, migraine, pusing dll (Muhammed, 2016).

Prisma pada penglihatan binokuler tidak selalu berdampak buruk. Prisma juga dapat digunakan sebagai media pengobatan. Optometris meresepkan kacamata prisma hanya untuk pasien berkebutuhan khusus seperti penderita strabismus. Tujuan dari pemberian lensa tersebut adalah membuat dan melatih otot mata penderita strabismus untuk kembali normal. Jika mata pasien harus "ditarik" ke bawah maka dapat digunakan prisma dengan posisi base ke atas dan apex ke bawah dengan demikian posisi bayangan yang terlihat akan berpengaruh pada mata (Chapman, 2012). Jika lensa prisma diberikan kepada orang normal, maka sebaliknya, otot mata orang tersebut dibuat untuk berperilaku tidak normal.

\section{KESIMPULAN}

Berdasarkan penelitian yang dilakukan, terdapat efek prisma horizontal pada pemakai kacamata dengan besaran terbesar $2.1-4.0 \Delta$ sebanyak 16 orang dominasi base in untuk mata kanan, dan 0.5 $2.0 \Delta$ sebanyak 19 orang dominasi base out untuk mata kiri. Serta efek prisma vertikal dengan besaran terbesar $3 \Delta$ dominasi base up.

Keluhan pada lensa single vision tidak akan begitu terasa sampai kekuatan lensanya tinggi. Oleh karena itu untuk penelitian selanjutnya, disarankan untuk menggunakan kacamata jenis lensa lainnya seperti bifocal atau progressive. Keluhan akibat desentrasi kecil pada lensa bifocal dan progressive akan lebih mudah teridentifikasi. 


\section{UCAPAN TERIMA KASIH}

Terima kasih kepada P3M STIKes Bakti Tunas Husada yang telah memberikan bantuan pendanaan sehingga penelitian ini bisa terlaksana.

\section{DAFTAR PUSTAKA}

Brooks, C. W. (1992). Understanding Lens Surfacing. USA: Butterworth-Heinemann. Elsevier Inc.

Brooks, C. W., \& Borish, I. M. (2007). System of Opthalmic Dispensing. Philadelphia, USA: Butterworth-Heinemann. Elsevier Inc.

Bruce, A. S. (2013). Vertically Challenge Part 1. Retrieved from Jobson Medical Information LLC website: https://www.2020mag.com/ce/vertically-challenged---part-4A032

Chapman, P. (2012). Prism Doesn't Have to be Perplexing. Retrieved from https://www.google.com/search?q=prism+doenst+have+to+be+perplexing\&oq=prism+doenst + have+to+be+perplexing\&aqs=chrome..69i57.9410j0j4\&sourceid=chrome\&ie=UTF-8\#

Erickson, E. (2016). 3. Notes on Optics: Prentice's Rule and More. Retrieved from Optician Notes website: https://opticiannotes.wordpress.com/2015/11/12/3-notes-on-optics-part-b-prenticesrule-prisms-thickness-and-aberrations/

Giancoli, D. (2005). Physics: Principles with Applications. Sith Ed. USA: Pearson Education Inc.

Husna, H. N., Bambang, F., \& Sari, D. L. (2018). Penyimpangan Titik Pusat Optik Lensa (OC) dengan Jarak Pupil Pemakai Kacamata (PD). Wahana Fisika, 3(2), 124. https://doi.org/10.17509/wafi.v3i2.13505

Husna, H. N., \& Yulianti, A. M. (2019). Lens decentration of spectacle wearers. AIP Conference Proceedings. https://doi.org/10.1063/1.5141632

Keirl, A. (2014). C38640: Essential Course in Dispensing - Part 17. Retrieved from Optician website: https://www.opticianonline.net/cet-archive/49

McCarthy, P. (2010). Back to Basics in Dispensing. Part 8 - Anisometropia. Optician, 18-21. Retrieved from http://assets.markallengroup.com/article-images/imagelibrary/147/uploads/importedimages/b2b.pdf

Milodot, M. (2009). Dictionary of Optometry and Visual Science (7th ed.). USA: ButterworthHeinemann. Elsevier Inc.

Moodley, V. R., Kadwa, F., Nxumalo, B., Penciliah, S., Ramkalam, B., \& Zama, A. (2011). Induced prismatic effects due to poorly fitting spectacle frames. African Vision and Eye Health, 70(4), 168-174. https://doi.org/10.4102/aveh.v70i4.115

Muhammed, F. (2016). Optical Prism Decentration. Retrieved from Slide Share website: https://www.slideshare.net/faslu1143/optical-prism-decentration

Poudel, A. (2019). Prism: Clinical Use in Optometry \& Opthalmic's Equipment. Retrieved from https://www.slideshare.net/bipinkoirala3/real-prism-use-in-ophthalmology

Sidarta, I. (2004). Kelainan Refraksi dan Koreksi Penglihatan. Jakarta: Balai Penerbit FKUI.

Smith, M. E., Kincaid, M. C., \& West, C. E. (2002). Basic Science, Refraction, and Pathology. The Requisites in Ophthalmology (9th ed.). USA: Mosby Inc.

The International Agency for the Prevention of Blidness. (2019). Global Vision Impairment Fact. Retrieved from The International Agency for the Preventionof Blidness (IAPB) website: https://www.iapb.org/vision-2020/who-facts/

Valiyaveettil, B., Prabhu, P. B., T., A. P., \& Vallon, R. K. (2018). Predictors of Unwanted Prismatic Effect Among Bespectacled With Displaced Optical Centre. Delhi J Ophthalmol, 28, 29-31. https://doi.org/Doi; http://dx.doi.org/10.7869/djo.330

Wakefield, K. G., \& Bennett, A. G. (2000). Bennett's Opthalmic Prescription Work. ButterworthHeinemann.

Wilson, D. (2019). Opthalmic Prism. In Global Optometry Resources. Retrieved from https://learning.brienholdenvision.org/courses/13/pages/applied-optics. 